Elementary

Aspects of

the Political 


\section{Theory in Forms}

A series edited by Nancy Rose Hunt and Achille Mbembe 


\section{Elementary Aspects of the Political}

Histories from the Global South

\section{Prathama Banerjee}

Duke University Press Durham and London 2020 
(C) 2020 Duke University Press

All rights reserved

Printed in the United States of America on acid-free paper $\infty$

Designed by Aimee C. Harrison

Typeset in Portrait Text and Univers LT Std by Copperline

Book Services

Library of Congress Cataloging-in-Publication Data

Names: Banerjee, Prathama, author.

Title: Elementary aspects of the political : histories from

the Global South / Prathama Banerjee.

Other titles: Theory in forms.

Description: Durham : Duke University Press, 2020. | Series:

Theory in forms | Includes bibliographical references and index.

Identifiers: LCCN 2020016390 (print)

LCCN 202001639I (ebook)

ISBN 978I478009870 (hardcover)

ISBN 978I4780I0906 (paperback)

ISBN 978I4780I2443 (ebook)

Subjects: LCSH: Political science-India. | Political

science-Philosophy.

Classification: LCC JA84.I4 B364 2020 (print) |

LCC JA84.I4 (ebook) | DDC 320.0I-dc23

LC record available at https://lccn.loc.gov/2020016390

LC ebook record available at https://lccn.loc.gov/20200I639I

COVER ART: Rana Begum, No. 394 L Fold, paint on mild steel, 20I3. Courtesy of the artist. 
To my little Chiku (2002-20I4) and his unforgettable courage and cool 
This page intentionally left blank 